\title{
THE CELTIC BISHOPS IN THE ISLE OF MAN, THE HEBRIDES AND ORKNEYS.
}

In 1154, Anastasius IV confirmed the incorporation of the two insular sees of the Orkneys and of Sudreys and Man in the metropolitan province of the Norwegian church, which had been organized by the cardinal-legate Nicolaus Brekespeare in 1152. At that time Christianity had, for 150 years, been the official religion of the Norwegian population of those isles.

The Orkneys were christianized, in 995, by the Norwegian king Ólafr Tryggvason, and as early as the middle of the following century the jarlar (i. e. counts) of the Orkneys gave the church in the isles a stronger organization, erecting an episcopal residence, the incumbents of which were consecrated by archbishops on the continent or in England, and thus from the very first directly connected with the Roman mother-church.

In the Norwegian colonies in the Sudreys (Hebudae, Hebrides) and in Man, the Norsemen seem to have accepted the Christian religion at the same time as their kinsmen in the Orkneys, although historical proofs are still lacking. As early as the second half of the eleventh century bishops with Norwegian names are found in Man, from which it is clear that the church of this island was organized by the Norwegian colonists. The contemporary state of Christianity in the Sudreys we do not know. When, in 1079, Guðrǫor Crovan had united the small kingdoms of these islands with Man, the ecclesiastical government of the church of the whole realm seems to have been committed to one bishop. The fact of the church of the united islands now paying obedience to an English metropolitan (York) seems to justify the conclusion that something like this had been 
the case also before the union of the islands took place; thus these newly founded Norwegian congregations from their very origin must have been rooted in the Roman Church.

In all these islands, however, Christianity is far older than the conversion of the Norwegian colonists to the Christian faith in its Roman form. For centuries before it had existed among the original Celtic population of the isles in its peculiar Irish form, and before the tempests of the viking-period one little island among the Hebrides had even been an important centre of missionary labour and Church culture: Hi (Iona).

\section{Man and the Hebrides.}

Apart from the rich information obtainable from Adamnan's Life of Columba and the Irish Annals very little is known from written sources about Christianity or the Church in Man and the Hebrides before the Norwegian occupation. The Liatin chronicle of the kings of Man and the Sudreys ${ }^{1}$ ), written in Man between 1250 and 1260, contains no original information on the history of these islands till the second half of the eleventh century. The small chronicle of the bishops of Man and the Sudreys, which forms an appendix to the chronicle of the kings, ${ }^{2}$ ) commences at the same time, but it does not tell us anything about Church events before the time of the first Norwegian bishop, Roolwer; nor was it possible for the author to give us any such information, as he himself tells us; he did not know anything, he found nothing in writing, and could obtain no certain information from old people: 'Multi quidem a tempore beati Patricii, qui primus fidem catholicam prodicasse fertur Mannensibus, exstiterunt episcopi, sed ab ipso [i. e. Roolwer] sufficit episcoporum memoriam inchoasse. Sufficit, dicimus, quod qui vel quales ante ipsum episcopi exstiterunt, penitus ignoramus, quia nec scriptum invenimus, nec certa relatione seniorum didicimus.' 3 )

1) Best edition by P. A. Munch, The Chronicle of Man and the Sudreys (Christiania 1860).

2) Munch, 28-31.

3) Munch, $28 \mathrm{f}$. 
The chronicles of the kings and bishops of Man and the Sudreys were first published by William Camden in his geographical description of Britain ('Brittannia' 1586), and have since been reprinted many times. ') The chronicles of the bishops were used by historians as early as the seventeenth century, and from this time onward one finds in a good many works lists of bishops of Man and the Sudreys, ${ }^{2}$ ) taken from the same source. But as it passes from author to author, the list has from time to time increased in length, not only downward, the recent bishops being successively included, but also upward; thus P. B. Gams (1873) $\left.{ }^{3}\right)$ enumerates no less than $10-11$ bishops before Roolwer, the first name in the old Latin list. In the latest publications by A. W. Moore $(1893,1900)^{4}$ ) and W. Stubbs $\left.(1897)^{5}\right)$ most of these bishops, or all, are omitted. But nowhere will be found any valuable and sufficient reference to sources regarding these supposed bishops; it is not known, whether they have existed or not as bishops in Man or in the Hebrides; generally will be found in these lists the mere names only and at times some scanty and uncertain chronological and personal dates; the proofs of the author - if such there are - mostly consisting only in references to some other recent author, whose words naturally have not the value of primary sources.

As, however, passages mentioning some of these ante-Norwegian bishops occasionally occur in mediæval sources, I was led to examine this matter more closely. ${ }^{6}$ ) And I have come to the conclusion, that only a few of these bishops can possibly be considered as historical personages; most of them are the creations of uncritical historians. We also find some names that were unknown to the writers of the seventeenth and eighteenth centuries. 1913), 310.

1) See the bibliography in Diplomatarium Norvegicum XVII B (Christiania

2) For the bibliography see ib., 310-311.

3) Series episcoporum ecclesiæ catholicæ (Ratisbonæ 1873), 197.

4) Diocese of Sodor and Man (1893); A History of the Isle of Man (1900).

5) Registrum sacrum Anglicanum (2. ed., Oxford 1897).

6) The result is inserted in my catalogue of the archbishops and bishops of the Norwegian Church before the Reformation in Diplomatarium Norvegicum XVII B (Christiania 1913, pp. 311-318). The following extract has been translated by the author from the Norwegian edition. 


\section{Man.}

Hector Boethius (1526) ${ }^{1}$ ) gives an account of Amphibalus as the first bishop at the Sodorense fanum in the island of Mona, being installed by the king of Scots Crathlinthus about A. D. 300 - Thomas Dempster (1627) 2) : Amphibalus I (!) A. D. 222, Amphibalus II (!) A. D. 325; John Spotswood (1655)'): A. D. 360 - This is a fable invented by Hector or maybe his authority Veremundus, and founded on the Legenda S. Albani, which tells about the flight of S. Amphibalus to Wales. ${ }^{4}$ ) The name 'Amphibalus' itself did not exist before the middle of the twelfth century, when Geoffrey of Monmouth $(+1154)$ happened to misunderstand a corrupt passage in the text of Gildas; this has been demonstrated by Ussher ${ }^{5}$ ) and recently once more by J. Loth. ${ }^{6}$ ) The feast of S. Amphibalus was on June 25. ${ }^{7}$ )

Germanus ${ }^{8}$ ) (Manx Karman $\left.{ }^{9}\right)$ ) is said by Joceline $\left.(1183 / 85)^{8}\right)$ and the Manx tradition (sixteenth century) ${ }^{\circ}$ ) to have been installed by S. Patrick ( $\dagger 459$, March 17) as the first bishop of Man (see a, b). - Feast: July $3^{10}$ ) (see c). - Dedication: Keeill Charmane $\left.^{9}\right)=$ ecclesia S. Germani in Holm Peel, the cathedral of Man (see d).

1) Scotorum historia lib. IX ( ${ }^{2}$ Parisiis 1574, fol. 98 $\left.{ }_{73}-99_{10} \cdot{ }_{24}-27\right)$.

2) Historia ecclesiastica gentis Scotorum, nr. 16 and 24 ( ${ }^{2}$ Bannatyne Club XXXIV, 19. 24).

3) History of the Church of Scotland 4 (1851) I, 6.

4) The legends are to be found in A.S. Boll. (i. e. the 'Acta Sanctorum' edited by the Bollandists) 22/VI. ${ }^{3} \mathrm{XXV}, 126-148$, cf. ${ }^{3} \mathrm{XXVI}, 325$; - excerpta from different authors by Jacobus Usserius (Ussher), Britannicarum ecclesiarum antiquitates, Dublinii 1639, 149-168. 193f. 983-985; - folklore tradition by W. Blundell, in Manx Society XXVII, 123; - a survey of unprinted legends by Th. D. Hardy, Descriptive Catalogue of Materials Relating to the History of Great Britain and Ireland I, 4-22. III, 265; R. Stanton, A Menology of England and Wales (London 1887), 290.

5) Antiquitates, 538-540.

6) Revue Celtique XI (1890), 348f.

${ }^{7)}$ A. S. Boll. ${ }^{3}$ XXVI, 325; S. Baring-Gould and John Fisher, The Lives of the British Saints I (London 1907), 153.

8) Jocelini Vita S. Patricii c. 79. 134 (A. S. Boll. 17/III. ${ }^{3}$ VIII, 556. 568).

9) The Ballad of Mamuanan beg mac y Leirr, composed in 1507 or a short time afterwards (printed according to an old: undated paleotype by Joseph Train, An Historical and Statistical Account of the Isle of Man, Douglas 1845, I, 50-55, and in Manx Society), vv. 13-16.

10) J. Colganus, Trias thaumaturga (Lovanii 1647), 113; A. S. Boll. 3/VII. ${ }^{3}$ XXVIII, 586. 
a) Joceline makes Germanus take up his episcopal residence in Insula Patricii $=$ Holm Peel. S. Patrick's visit to Man is told only by Joceline, the Latin chronicle of the bishops of Man and the Sudreys, and the ballad of Mannanan, and is thus proved to be a purely Manx tradition, as Joceline, abbot of Furness in Cumberland, probably got his knowledge from the monks in Rushen in Man (who were subjected to him), the later authors of the chronicle of the bishops.

b) Ussher ${ }^{1}$ ) says that Germanus became bishop in 447 and died in 474 (C. O'Conor ${ }^{2}$ ): A. D. 447, A. D. 471), but here I cannot find any older authority; as Ussher often quotes Irish annals, he may have found it in the Annals of Tigernach, which now have a gap for these years, but may have been more complete in the time of Ussher.

c) Whitley Stokes ${ }^{3}$ ) incorrectly takes the German mentioned in Irish martyrologies under July 30 to be the bishop of Man instead of the wellknown bishop of Auxerre.

d) Several others have tried to connect the bishop of Man with different persons of the name of Germanus, Gorman, or Garmon 4); this is, however, very doubtful, as J.Lani$\operatorname{gan}^{5}$ ) has shown. If we cannot, according to J. Shearman 4 ), identify bishop Germanus of Man with the British saint Garmon, the son of Rydigus ${ }^{6}$ ), we may follow J. Train ${ }^{7}$ ) and J.R. Oliver ${ }^{8}$ ), who see in him a localisation of Germanus of Auxerre ( $f$ 448, July 30 ) who visited England in 429 and 446 on the occasion of the Pelagian heresy, and who was in other ways connected with S. Patrick.

1) Antiquitates, 1113. 117.

2) Rerum Hibernicarum scriptores II 1, 106. $114 \mathrm{f}$.

3) The Martyrology of Gorman (Henry Bradshaw Society IX), 368; cf. supra note $d$.

) J. Ussher, Antiquitates, 842f.; J. Colgan, Trias thaumaturga, 113. 196 f.; J.F. Shearnan, in Journal of the Kilkenny Archæological Society 4 III (1874); 410-413, cf. 4 IV (1876), 69. 443f.; S. Baring-Gould and J. Fisher, British Saints I, 96. $291-293.301$.

5) An Ecclesiastical History of Ireland I (Dublin 1822), 305-307.

o) ef. Lives of the Cambro-British Saintb, ed. W. J. Rees (Welsh MISS. Society, Llandovery 1853), 270.599.

7) Bishop series, in his Account of Man I, 308-379. 396.

8) Manx Society $X V, 65$. 
Coninnrí and Rómul are in most Vitæ S. Patricii ${ }^{1}$ ) mentioned as the first contemporaneous bishops in Man (see a); middle of the fifth century (see b, c).

a) Joceline is the sole author who speaks of S. Patrick consecrating them bishops; J.Lanigan ${ }^{2}$ ) therefore justly doubts this account; otherwise it seems, as if S. Patrick, possessing no very considerable prestige, did not consecrate any bishop in the whole of his life time. ${ }^{3}$ )

b) J. Ussher, 4 ) without referring to any authority, puts the death of both of them in 498 .

c) The informations of J. Colgan 5) on the festivals of these two men, November 17 and 18, arose from a misunderstanding of his sources. Coninnri I have not been able to find in Irish martyrologies, but a Rómul is named on the 4 th of May in the martyrology of Gorman $\left.(1116 / 74)^{6}\right)$.

${ }^{7)}$ Mace Cuill ${ }^{\text {) }}$ (Manx: Maughold ${ }^{9}$ )) moccu Grecce ${ }^{10}$ ) (also 'Cyclops' ${ }^{10},{ }^{11}$; a robber from Druimm moccu Echach ${ }^{10}$ ) in Ulster,

1) Muirchu maccu Machtheni (seventh century), ed. Whitley Stokes in The Tripartite Life of St. Patrick (Rer. Brit. scr. 89), 286-289: Conindri et Rumili, var.: Conhindri et Romuli; - Eleranus (ninth century), Colgan's 'quarta vita', c. 81-82 (Trias thaumaturga, 45): Conindrius et Romulus; Benignus (tenth century), Colgan's 'tertia vita', c. 73 (ib., 27); - Probus (tenth century), Colgan's 'quinta vita', II c. 9-11 (ib., $56 \mathrm{f}$.): Conindrus et Romulus; - Vita tripartita (eleventh century), ed. Whitley Stokes, 220. 222: Coninnrí and Romuil; - Jocelinus (1183/5) c. 132-134 (A. S. Boll. 17/III. ${ }^{3}$ VIII, 568): Connidrius et Romulus.

2) Eccl. Hist. I, 307.

3) H. Zimmer in J. J. Herzog's Realencyklopädie für protestantische Theologie und Kirche ${ }^{3} \mathrm{X}, 219$.

4) Antiquitates, 1122.

5) Trias thaumaturga, 50.

6) ed. Whitley Stokes, 90.

7) The sources are quoted under Coninnri and Rómul; we may also add the Homily on S. Patricius in Lebar Brecc (thirteenth century), ed. Whitley Stokes, in The Tripartite Life of St. P., 482; cf. also a legend by A.W. Moore, The Folklore of the Isle of Man (Douglas and London 1891), 21f., and the popular poem in Manx Society XVI (1869), 220-222.

8) So Muirchú, Vita tripartita, and the Homily in Lebar Brecc; (tertia vita: Maguil; quinta vita: Macfail; Joceline: Machaldus).

9) The Ballad of Mannanan beg mac y Leirr, vv. 17-19.

10) Muirchu.

11) Quarta vita. 
converted in Mag-Inis [Lecale in Ulster] by S. Patrick [ $\boldsymbol{t}^{-}$in 459], baptized in Man by Coninnri and Rómul) succeeded them as bishop, episcopus et antistes Ardda Huimnonn (var.: Ardde Uiminen $)^{2}$ (end of fifth century [see a]). - Feast: April 25 ${ }^{2}$ ) (see b). - Dedications (see c): 1. Kirk Maughold in $\operatorname{Man}^{3},{ }^{4}$ ); 2. S. Maugand near Montfort in Brittany. ${ }^{5}$ )

a) J. Ussher ${ }^{6}$ ) gives A. D. 498 as the year of Macc Cuill's succession; he probably meant A. D. 489; as two MSS. of the Ulster Annals 7) here say: Quies (i. e. death) MCaille Episcopi Mannensis; but the word Mannensis is added by a later hand, and it is not mentioned in Tigernach's Annals, ${ }^{8}$ ) nor in the Annals of Innisfallen ; ${ }^{9}$ ) it arose from a confusion with Mac Caille, a bishop in Cruachan Brig Eile (i. e. Croghan in King's Co.) in the fifth century. This same mistake underlies the story of Hector Boethius (1526), ${ }^{10}$ ) that an [unnamed] Sodorensis episcopus in the island of Mona gave S. Brigit the veil. Later authors have interpreted this account as relating to bishop M. of Man. ${ }^{11}$ ) P. Heylyn (1671) ${ }^{12}$ ) probably took the year 518 from Thomas Dempster (1627), ${ }^{13}$ ) who gives this date also as the year of S. Brigit's death. The year 578 given by W. Sacheverell (1702) ${ }^{14}$ ) arose from an error in his copy of Heylyn's work. I cannot explain the years 553 and 554, which are also given.

1) Vita tripartita.

2) A. S. Boll. 25/IV. ${ }^{3} \mathrm{XII}, 370 \mathrm{f}$.

3) Joceline; cf. the legend in Chron. reg. Mann. A. D. 1158, p. 10-12.

4) See page 362 , note 9 .

5) S. Baring-Gould and J. Fisher, British Saints I, $61 \mathrm{f}$.

-) Antiquitates, 1112.

7) ed. W. M. Hennessy (Dublin 1887-1901) I, $28 \mathrm{f}$.

8) ed. Whitley Stokes in Revue Celtique XVII (1896), 120.

9) ed. C. O'Conor in Rer. Hib. scr. II 2, p. 4, A. D. 484.

10) Scotorum hist. lib. IX ( 2 fol. $\left.158_{57}-65\right)$.

11) cf. moreover J. Lanigan, Hist. Eccl. I, 386-388; A. S. Boll. 1/II. 1V, 104-105; J. O'Hanlon, Lives of Irish Saints IV, 480. 483.

12) Bishop series in the third (posthume) edition of his Help to English History ( $\left.{ }^{1} 1641 .^{2} 1652 .{ }^{3} 1671\right), 182-184$.

13) Hist. Eccl. 2, 82.

14) Bishop series in his Account of the Isle of Man, ${ }^{2}$ ed. J. G. Cumming, in Manx Society I (1859), 82-92. 
b) W. Blundell ') tells about a market at Kirk Maughold on October 25, and a smaller fair held in the beginning of August.

c) A. P. Forbes ${ }^{2}$ ) mentions Kilmaichlie in Inveravon parish in Co. Banff in Scotland; but this name was probably derived from macLoig. ${ }^{3}$ ) J. Train ${ }^{4}$ ) also refers to $M$. the churches in Wigtown (Galloway) and Lesmahago (Lanarkshire); but they were dedicated to S. Machutus [i. e. Maclovius, bishop of Alet in Brittany $\left.{ }^{5}\right)$, whose name recent authors, following the example of the chronicles of the kings and bishops of Man and Sudreys, often substitute for S. Maughold.

Ma Rooney is by Manx tradition (sixteenth century) ${ }^{6}$ ) said to have been bishop in Man [after Maughold]; he was buried in Keeill MaRooney (see a). - Dedication: Kirk Marown [= Keeill Ma Rooney] in Man (see b).

a) As Lonnan (see below) and Connaghan (see below) were buried in the same church, they must have lived after Ma Rooney, although the ballad mentions them before him.

b) In names like $M a$ Rooney we have the hypocoristic ma (originally mo), poss. pron. 'my'. The name itself is doubtless the Irish Rónán, by which a great many unlocalized saints are called in the martyrologies. ${ }^{7}$ ) Perhaps we may, following A. W. Moore, ${ }^{8}$ ) suppose him to be the Scottish abbot Rónán of Cinngarad [i. e. Kingarth in Bute], who died A. D. 737, Febr. 7 (9), and wo is commemorated in many place names in the Hebrides. ${ }^{9}$ ) Thus we may regard the 'bishop' of Man as a localized eponymous saint.

1) Manx Society XXVII, 128.

2) Kalendars of Scottish Saints (Edinburgh 1872), 380.

3) Conjectured by Professor C. Marstrander in Christiania.

4) Supra p. 361, note 7 .

5) Forbes, Kalendars, 381.

6) The Ballad of Mannanan, vv. 19-20.

7) See J. O'Hanlon, Lives of Irish Saints, under 11/I., 13/I., 6./II., 7./II., 9./II., 17./II., 1./V., 20./V., 21./V., 22./V:, 1./VI., 15./VII., 18./VIII.

8) A History of the Isle of Man (London 1900), 75.

9) Forbes, Kalendars, $441 \mathrm{f}$; see below, p. 373. 
Lonnan was, according to the Manx tradition (sixteenth century), ${ }^{1}$ ) bishop in Man [after Ma Rooney], buried in Keeill Ma Rooney. - Dedication: Kirk Lonan in Man (see a).

a) L. is perhaps identical with one of the numerous Irish saints of the name $\operatorname{Lom}(m)$ an or $\left.\operatorname{Lon}(n) a n .{ }^{2}\right) \quad$ J. G. Cumming $^{3}$ ) and W. Harrison ${ }^{4}$ ) identify Lonnan as a matter of course with Loman, the first bishop of Tuam in Ireland, fifth century; but this combination is devoid of any authority.

Connaghan was, according to the Manx tradition (sixteenth century), ${ }^{5}$ ) bishop in Man [after Ma Rooney]; he lies buried in Keeill Ma Rooney. - Dedication: Kirk Conchan in Man (see a).

a) C. may be a localization of the Scottish bishop Connanus, whom Hector Boethius (1526) calls episcopus Sodorensis (vide infra p. 367-368).

..... (see a) EPiscoPuS dEI INSVLE (see b) names himself in an inscription in Irish-Anglosaxon letters from the eighth or ninth century in a cross stone in Kirk Maughold in Man. ${ }^{\text {) }}$

a) Before the word EPPS is written [NO]NEITSPLI (Kermode has read the letters NO on p.74, but omitted them on p. 111); but this name is neither of Celtic nor of German origin.

b) Kermode has not been able to read with certainty the last-letter of this word; but it cannot be anything else but $\mathrm{E}$, which also the plate seems to show.

After William (bishop in Man about 1060/70) Browne Willis $(1727-30)^{7}$ ) mentions a certain bishop Brendinus, to whom

1) The Ballad of Mannanan, vv. 19-20. 11./VIII.

2) See J. O'Hanlon, Irish Saints, under 4/II., 7/II., 17/II., 6./VI.,

3) Manx Society X, 74 .

4) Bishop series in his Account of the Diocese of Sodor and Man, in Manx Society XXIX (1879), 53-69.

5) The Ballad of Mannanan, vv. 19-20.

6) Found during the reparation of the shurch in 1900 , described by P. M. C. Kermode, Manx Crosses (London 1907), 74f. 111 f.

7) Bishop series in his Survey of the Cathedrals of York, Durham \&c. (London 1727-1730, 2 1742), reprinted in Manx Society XVIII, 133-141. 
he says one of the churches in Man was dedicated. $R$. Keith $(1755)^{1}$ ) adds Brandanus as a recognised better form of the name, and says that the church is Kirk Braddan. Abbé Pétin $\left.(1851)^{2}\right)$ under November 2 puts Brendan, bishop in Man, in the ninth century. W: Harrison ${ }^{3}$ ) refers Brandon quite arbitrarily to A. D. 1025. - Probably this 'bishop' is eponymous, Kirk Braddan being by A. W. Moore") supposed to be a commemoration of the famous sailor Brénainn mac Findloga, abbot of Clonfert in Ireland, $t$ A. D. 576 May 16, who on his extended voyages visited both Wales [and Man?] and the Hebrides, and of whom numerous commemorations are to be found in the place names of the Hebrides, - provided that these are not due to the contemporary abbot Brénainn of Birra, $t$ A. D. 571/73 November 29, who as Brénainn of Clonfert was connected with Columcille. ${ }^{5}$ ) R. Challoner (1761) ${ }^{6}$ ) mentions under October 20 the feast of S. Bradanus and S. Orora in Man. ${ }^{7}$ ) - It is, however, not improbable that it refers to Brendinus Enbonice regulus (end of the sixth century), who is mentioned by Johannes de Fordun († about 1386). ${ }^{8}$ )

\section{The Hebrides.}

Petrus de Natalibus (bishop of Equilio in Italy from 1370) in his Catalogus sanctorum ${ }^{9}$ ) mentions a certain Macririus episcopus, a maternal brother of S. Ursula (fourth century), whom Thomas Dempster $(1627)^{10}$ ) calls episcopus in Scotia, et quidem Sodorensis (!), † A. D. 454 October 21.

1) Bishop series in his Large New Catalogue of the Bishops of the Several Sees of the Kingdom of Scotland (Edinburgh 1755), 175-181.

2) Dictionnaire hagiographique (J. P. Migne's Encyclopédie théologique $1 \mathrm{XL}, 1851), 482$.

3) Vide supra p. 365 , note 4.

4) Hist. of Man, p. 75, note $\|$.

5) See J. Lanigan, Hist. eccl. II, 28-41; S. Baring-Gould and J. Fisher, British Saints I, 233-262.

6) Memorials of Ancient British Piety (1761), 137.

${ }^{7}$ cf. A. S. Boll. 20/X. ${ }^{3}$ LVI, $887-890$.

8) Chronica gentis Scotorum III c. 28 (ed. W. F. Skene, Historians of Scotland I, 114).

9) [Vicenza] 1495, lib. IX c. 87 ('de sanctis undecim milibus uirginibus').

10) Hist. eccl. $\mathrm{nr} .888$ ( $2469 \mathrm{f}$.). 
In the Vitæ S. Brigidæ 1/II. and the Vitæ S. Tigernachi 5/IV. a certain Condlaed is mentioned, a hermit from the River Liffey in Leinster in Ireland, whom S. Brigida appointed bishop in the neighbouring see of Kildare about A. D. 490,1) and whose name is found in Irish and Scottish martyrologies under May 3.2) In the account of the meeting of the hermit and the virgin in the 'quarta' Vita S. Brigidæ, ${ }^{3}$ ) the title episcopus is anticipated, and in the 'secunda' Vita ${ }^{4}$ ) C.'s vestimenta transmarina et peregrina are mentioned. It is then probably by a loose surmise that D. Camerarius (1627) ${ }^{\mathrm{s}}$ ) (or the authors to whom he refers, Alexander Millius and Georgius Neutonus?) has chanced to give Conleatus - the name is corrupted later into Contentus - the title of episcopus Sodorensis; he places him under March 15 and omits the bishop of Kildare May $3 .{ }^{6}$ )

Hector Boethius (1526) in his Scotorum historia ?) speaks of one Connanus, episcopus Sodorensis, who was teacher to the three sons of King Eugenius, one of whom was the later saint S. Fiacrius. We find, however, nothing in the Vitæ S. Fiacrii about this bishop $;^{8}$ ) the Bollandists ${ }^{9}$ ) therefore place C. among 'prætermissi'. D. Camerarius $(1627)^{10}$ ) dates the feast of Conon siue Conanus January 26, and places his death at A. D. 648; Thomas Dempster (1627) ${ }^{11}$ ) gives November 24 and A. D. 664. The King Eugenius Aidani filius, called Brudus, who is mentioned by Boethius, ${ }^{12}$ ) is the king of Dalriada Eochaid Buide mac Aidan,

1) J. Lanigan, Eccl. hist. I, 409-415.

2) J. O'Hanlon, Irish Saints V, 69-95.

3) II c. 19 (J. Colgan, Trias thaumaturga, 552).

4) c. 19 (ib., 522).

5) De statu hominis, veteris simul ac novæ ecclesiæ, et sanctis regni Scotiæ (Catalanni 1627), 167; cf. Forbes, Kalendars, 314.

o) cf. J. Lanigan, Eccl. hist. I, 409; J. H. Todd, St. Patrick, Apostle of Ireland (Dublin 1864), 23 f.; A. S. Boll. 3/ V. ${ }^{3}$ XIV, 363.

${ }^{7)}$ Lib. IX (2 fol. $\left.173_{8}-{ }_{13}\right)$.

s) A. S. Boll. $30 /$ VIII. ${ }^{3} \mathrm{XL}, 604-616$; L. Surius, Historiæ seu vitæ sanctorum (Augustæ Taurinorum 1875-80) VIII, 745-747; Novæ legendæ Angliæ, ed. C. Horstman (Oxford 1901) I, 441-444.

9) A. S. Boll. 26/I. ' III, 305.

10) De statu hominis, $135 \mathrm{f}$.

11) Hist. eccl. nr. 256 ( $\left.{ }^{2} 153\right)$.

12) Lib. IX ( ${ }^{2}$ fol. $\left.171_{57}-88\right)$. 
† A. D. $629 ;^{1}$ ) but no Irish or Scottish sources give any son of his called Fiacrius. ${ }^{2}$ ) As regards C.'s existence we have evidence in Scottish place names. ${ }^{3}$ )

The Breviary of Aberdeen (1509)4) contains five lections on $S$. Talaricanus, who is said to have been consecrated bishop by a certain pope Gregorius and afterwards to have worked in borealis Scocie plaga. Thomas Dempster (1622) ${ }^{5}$ ) relates, that $S$. Tarkinus was commemorated in Lismore October 30, and therefore (in 1627) assumed (ut existimo) ${ }^{6}$ ), that he could give $T$. the title of episcopus Sodorensis. Adam King (1588) ${ }^{\top}$ ) says, that $S$. Tarkin lived vnder king soluathius A. D. 889. - Probably the association with the Hebrides arose before Dempster's time, and W. Camden, taking the nearest pope, Gregorius IV $827-843 / 44$, gave the following account in the enlarged (folio) edition of his Brittannia (London 1607)8): Inter opida [Mannice] procipuum censetur Russin, ad Australe latus situm, quod à castro vbi prosidium habetur vulgò Castletown appellatur, vbi in insula sedes Episcopalis à Gregorio Quarto Pontifice Romano fuit instituta, cuius episcopus Sodorensis dictus ab hac ipsa insula (vt creditur) iurisdictionem in omnes Hebridas insulas olim habuit, nunc tantum \&c. (the words from $v b i$ are missing in the edition of 1594) ${ }^{\circ}$, and after that time invariably by later authors, and even at the present time, we meet the account, that Gregorius IV founded the episcopatus Sodorensis in 838,844 or 847 . However, this proves to be a fiction, for we see that king Selvach mac Ferchair of Dalriada resigned in $723,+730^{10}$ ) and was thus a contemporary of pope Gregorius II $715-731$. It is therefore better 1862) II, 186.

1) E. W. Robertson; Scotland under her Early Kings (Edinburgh

2) W. Reeves, The Life of St. Columba written by Adamnan (Dublin 1857. Bannatyne Club CXI), 438 (the genealogical table); cf. J. O'Hanlon, Irish Saints VIII, 424f.

3) Forbes, Kalendars, 308; O'Hanlon I, 446-449.

4) Pars estivalis, proprium sanctorum, fol. cxxxiiiiv - vir (2 Bannatyne Club XCI [1853], 335-337).

5) Forbes, Kalendars, 216.

${ }^{\circ}$ Hist. eccl. nr. 1118 ( $\left.{ }^{2} 611\right)$.

7) Forbes, Kalendars, 166.

8) p. 839.

9) I have not had an opportunity of consulting the quarto edition of 1600 .

19) E. W. Robertson, Scotland I, 15. II, 186. 
to follow the Bollandists ${ }^{1}$ ) who place bishop T. at this date. Besides in the sees of Aberdeen, Ross and Moray, there are commemorations of T. also in the Hebrides: Ceill Tarraglan in Skye, and Eagluis Tarain in Taransay. ${ }^{2}$ )

In the Breviary of Aberdeen (1509)3) there are five lections on $S$. Volocus, a bishop who laboured in the northern part of Scotland 'after A. D. 400'; he is mentioned in the Kalendaries under January 294); Adam King (1588) ${ }^{5}$ ) names S. Makwolok bischop in scotland A. D. 720; Thomas Dempster (1627) ${ }^{6}$ ) makes S. Makuvolokus off hand episcopus Sodorensis A. D. CCCXX [i. e. DCCXX], while D. Camerarius (1627) ${ }^{i}$ ) places him in Candida Casa [i. e. Galloway]. As Volocus is a latinisation of Irish Faelchu, we may perhaps, with A. P. Forbes, ${ }^{8}$ ) suggest Faelchu mac Dorbéne, abbot of Hi A. D. 717-724.9)

Patrikr ('hinn helgi' i. e. 'the saint') was, according to the Icelandic Sagas, $\left.{ }^{10}\right)$ bishop $i$ Sudreyjum in the second half of the ninth century (see a).

a) This account of bishop Patrikr and Orlygr Hrappsson is generally considered a mere legend; ${ }^{11}$ ) we must, however, bear in mind, that Hector Boethius (1526) ${ }^{12}$ ) speaks of Patricianus episcopus, who being persecuted by the Anglosaxons fled to Scotland and (from the Scottish king Congallus) obtained land in the Island of Mona, where he died at the time of Congallus' successor Conranus. Perhaps Hector was wrong in placing $P$. at this period

1) A. S. Boll. 30/X. ${ }^{3} \mathrm{LXI}, 449$.

2) Forbes, Kalendars, 449.

3) Pars hyemalis, propr. sanct., fol. xliiiiv $-\mathbf{x l v v}$ (' Bannatyne Club CII [1854], $337-338)$.

4) A. S. Boll. 29/I. ' III, 531; J. O'Haulon, Irish Saints I, 504-506.

5) Forbes, Kalendars, 143.

e) Hist. eccl. nr. 848 ( $\left.{ }^{2} 452^{*}\right)$.

7) De statu hominis, 137.

8) Kaleudars, $459-461$.

9) W. Reeves, The Life of St. Columba, $381 \mathrm{f}$.

10) Landnámabók I c. 12 (f́slendinga sögur I [1843], 42f.); Olafs saga Tryggvasonar c. 119 (Fornmanna sögur I [1825]; 242f.) = c. 217 (Flateyjarbók I [1860], 264); Kjalnesinga saga c. 1 (Íslendinga sogur II [1847], 398).

11) e. g. vide K. Maurer, Die Bekehrung des norwegischen Stammes zum Christentume II (München 1856), 631 s24.

12) Scotorum historia, lib. VIII (2 fol. $\left.151_{72}-78\right)$. 
- Comgal mac Domangarto of Dalriada ruled A. D. 505-538, his brother Gabrán macDomangarto A. D. $538-560^{\prime}$ ) - or perhaps there have been several bishops named $P$. in the Sudreys; it is also possible that another bishop conceals his identity under the better known name of the great apostle S. Patrick. ${ }^{2}$ )

In the Vita S. Malachiæ archiepiscopi Armachani by Bernard of Clairvaux we find mention of bishop Malchus of Lismore (in Munster in Ireland) A. D. 1119/32 ${ }^{s}$, whose festival is April 10 $)$ or August 10.5) Thomas Dempster $\left.(1622,1627)^{6}\right)$ confounded the Irish see Lismore with Lismore in Argyle and tells that Malchus floruit A. D. 1161 (!). As Lismore is one of the Hebrides (although it was never included in the later 'diocesis Sodorensis', but formed a separate see), David Camerarius (1627, 1631) ${ }^{7}$ ) considered himself justified in calling $S$. Malchus episcopus Sodorensis in Scotia, but transferred him to August 30. Later authors have further confounded bishop Malchus (April 10) with the much earlier bishop Molocus ${ }^{8}$ ) or Mo Lugaid (June 25), bishop of Lismore in Argyle in the sixth century ${ }^{9}$ ).

\section{Hi (or I, Hy, Y) - I-Coluimcille - (latinised Ia, Ioua, corrupted to Iona).}

'Seven [contemporary] bishops in $\mathrm{Hi}$ ' are invoked in the socalled Litany of Engus ${ }^{10}$ ) [about A. D. 800 (see a)] and may perhaps be referred to the time about A. D. 500 (see b).

1) E. W. Robertson, Scotland II, 186.

?) cf. D. Camerarius, De statu hominis, 259; Forbes, Kalendars, 242. 214 ; A. S. Boll. 10/X. ${ }^{3} \mathrm{LIII}, 8$.

3) A. S. Boll. 3/XI. ${ }^{3}$ LXV, 146. 151, cf. 139.

4) O'Hanlon IV, 92-102.

5) O'Hanlon VIII, 148f.; A. S. Boll. 10/VIII. ${ }^{3} \mathrm{XXXVI}$; 561, cf. 30/IX. 3 XLVIII, 259. $\left(2452^{*}\right)$.

6) Menologium Scotorum by Forbes, Kalendars', 196; Hist. eccl. nr. 847

7) De statu hominis, 234; Forbes, Kalendars, 241.

8) Richard Augustine Hay, quoted by R. Keith, An Historical Catalogue of the Scottish Bishops, ${ }^{2}$ ed. M. Russel (Edinburgh 1824), 284.

9) Forbes, Kalendars, 409-411; A. S. Boll. 25/VI. ${ }^{3}$ XXVII, 677-680; O'Hanlon VI, 789- 795.

10) Secht n-epscoip na Hii and Secht n-epscoip Cille Hiae (quoted by W. F. Skene, Celtic Scotland II, 34). 
CELTIC BISHOPS IN THE ISLE OF MAN, ETC.

a) Provided that Engus really composed the litany, that generally bears his name.1)

b) The Catalogus Sanctorum Hiberniæ ${ }^{2}$ ), written in the eighth century, divides the time after S. Patrick into three periods, the first of which, asserted to have lasted until A. D. 534, is characterised by groups of bishops being consecrated seven at a time and labouring together. H. Zimmer ${ }^{3}$ ), however, assumes, that the views of this catalogue concerning the ecclesiastical state of Ireland in the fifth and sixth centuries were in the main produced or influenced by the legend of $S$. Patrick, as it arose in the seventh century.

Two bishops were in $\mathrm{Hi}$, when Columcille landed there in 563 , but they at once left the island (see a).

a) Thus says the Irish Vita S. Columbæ in Lebar Brecc ${ }^{4}$ ), written about A. D. 1397, and in the Book of Lismore ${ }^{5}$ ), written about A. D. 1460.

Fergna Brit mac Failbe, who was abbot of I-Coluimcille A. D. $605-\dagger$ A. D. 623 March $\left.2^{6}\right)$, is also called 'bishop' in a gloss to the Martyrology of Gorman '), in the Annals of the Four Masters ${ }^{8}$ ), and in the Martyrology of Dcnegal ${ }^{9}$ ).

1) cf. Whitley Stokes in Transactions of the Royal Irish Academy, Irish Manuscript Series I 1 (Dublin 1880), 4-6.

2) Councils and Ecclesiastical Documents Relating to Great Britain and Ireland, edd. A. W. Haddan et W. Stubbs II 2, 292-94.

3) J. J. Herzog's Realencyklopädie \& X, 209. 224.

4) Translated by W. M. Hennessy, by W. F. Skene, Celtic Scotland II, 491; the Irish text of this passage is quoted by W. Reeves, The Life of St. Columba, 435k. $4 \mathrm{~V})$, 30. 178.

5) ed. Whitley Stokes, Lives of Irish saints (Anecdota Oxoniensia

๑) W. Reeves, The Life of St. Columba, 372.

7) ed. Whitley Stokes, $46 \mathrm{f}$.

8) ed. J. O'Donovan [2] I (1851), $244 \mathrm{f}$.

э) edd. J. H. Todd and W. Reeves (Irish Archæological and Celtic Society VII, 1864), $60 f$. 
Coeddi, bishop of Ia, + A. D. $712^{1}$ ) October $24^{2}$ ).

Thomas Innes $\left.(+1744)^{2}\right)$ supposed, that the signature of the Acts of the Council in Cealchype (Chelsea) A. D. 7874): Ego Aldulphus Myiensis ecclesiae episcopus . . . should read Hyensis, but the editors of the Acts show ${ }^{b}$ that $A$. is the bishop of the Anglosaxon colony of Mayo (on the west coast of Ireland), who was consecrated A. D. 785.

Fingin, anchorite and bishop of $\left.\left.\mathrm{Ia}^{6}\right),+964^{7}\right)$ March $\left.5^{8}\right)$.

Mugróin, comarba [i. e. successor] of Columcille in Ireland and Scotland A. D. 964-A. D. $980^{\circ}$ ), in the Annals of the Four Masters ${ }^{10}$ ) is called 'abbot of Ia, scribe, and bishop'.

Maelciaráin Ua Maigne, comarba of Columcille 980-986 ${ }^{11}$ ), in the Annals of Innisfallen ${ }^{12}$ ) is called bishop of Ia.

Flaithbertach Ua Brolchain, comarba of Columcille from A. D. 1150, and abbot of $\mathrm{Hi}$ from A. D. 1164 $\left.{ }^{13}\right)$, was appointed bishop by the council of Bri-mic-'Taidg (co. Meath in Ireland) A. D. $1158^{13}$, † A. D. $1175^{14}$ ).

1) Annals of Tigernach, ed. Whitley Stokes, Revue Celtique XVII (1896), 222; Annals of the Four Masters, [2] I (1851), 310f.: A. D. 710; Annals of Ulster, ed. W. M. Hennessy (Dublin 1887-1901) I, 161: A. D. 711.

2) Martyrology of Tallaght, ed. M. Kelly in Catalogue of Irish Saints (Dublin 185̃7); Mart. of Donegal, $282 f$.

s) The Civil and Ecclesiastical History of Scotland (Spalding Club XVII 1853), 186.

4) Councils, edd. Haddan and Stubbs III, 460.

5) ib. III, 446. 462.

6) Annals of the Four Masters [2] I (1851), $686 \mathrm{f}$.; Chronicum Scotorum, ed. W. M. Hennessy (Rer. Brit. scr. 46), $216 \mathrm{f}$.

$\left.{ }^{7}\right)$ The year 964 in the Ann. of the Four Masters W. Reeves corrects into 966 (The Life of St. Columba, 395).

8) J. Colgan, Trias thaumaturga, 502.

9) W. Reeves, The Life of St. Columba, 394.

10) [2] I (1851), $708 f$.

11) W. Reeves, The Life of St. Columba, 395.

12) Rer. Hib. scr., ed. C. O'Conor II 2, 45 (the year 968 here corresponds with 986 in the other annals).

${ }^{13}$ ) W. Reeves, The Life of St. Columba, $406 \mathrm{f}$.

14) Annals of the Four Masters A. D. 1158, 1175. [2] II (1851), 1128f.; [1] I (1848), $18 \mathrm{f}$. 


\section{Cinngarad.}

(Kingarth in the island of Bute).

Daniel, bishop of Cinngarad, + A. D. 659.1)

Jolán, bishop of Cinngarad, + A. D. 688.2)

Rónán, abbot of Cinngarad, † A. D. $737^{3}$ ), is called 'bishop' in the Breviary of Aberdeen (1509) ${ }^{4}$ (see a).

a) A.P. Forbes ${ }^{5}$ undoubtedly makes a mistake in identifying this Rónán with the epscop Rónán in the martyrology of (Engus ${ }^{6}$ ) (February 9), - because in a gloss ${ }^{7}$ ) this bishop is called bishop of Lismore in Ireland. - Several place names, especially in the Hebrides, commemorate the abbot bishop Rónán. $\left.{ }^{8},{ }^{9}\right)$

Cathanus, bishop, according to the legend (1509) have consecrated his sister's son Blaán (see below) bishop, and is therefore referred to the island of Bute by .D. Camerarius $(1627) ;{ }^{11}$ ) C. quotes Georgius Neutonius, the Historia Dumblanensis and others. ${ }^{12}$ )

Blaán (see a), according to the legend $(1509)^{10}$ ) originated from the island of Bute, studied in Ireland, and after his return was consecrated bishop by his maternal uncle Cathanus (see the fore-going) and accepted apostolic benediction in Rome. - In Irish

1) Annals of Ulster I, $116 \mathrm{f}$.: A. D. 659; Annals of Tigernach (XVII), 195; Annals of the Four Masters [2] I (1851), 269f.: A. D. 659; Chron. Scotorum, 94 f.: A. D. 656.

2) Annals of Ulster I, 138f.: A. D. 688; Annals of Tigernach (XVII), 210; Annals of the Four Masters [2] I (1851), 294f.: A. D. 688; Chron. Scotorum, 108 f.: A. D. 685.

3) Annals of Ulster I, 192f.: A. D. 736; Annals of Tigernach (XVII), 240.

4) Pars hyemalis, propr. sanct., fol. liiii .

5) Kalendars, 441.

o) ed. Whitley Stokes (Henry Bradshaw Society XXIX 1905), 59.

7) ib., $73 f$.

s) Forbes, Kalendars, 441.

๑) cf. A. S. Boll. $7 /$ III. $\vee v, 2$.

10) Breviary of Aberdeen, pars estivalis, propr. sanct., fol. lexviir-v $(2$ 278).

11) De statu hominis, 197 (17; $\nabla$.$) .$

12) cf. A. S. Boll. 10/VIII. 'XXXVI, 484. 
martyrologies he is called bishop ${ }^{1}, 2^{2}$, ) or abbot*) of Cinngarad in Gall-Gáidil (i. e. Galloway) (see b), but his name is also connected with the church of Dumblane ${ }^{3}$ ); he is said to have lived about A. D. 1000 (see.c), + August 10. ${ }^{16}$ )

a) In the later bishop series the name is corrupted into Bladus or Baldus.

b) As Bute is one of the Hebrides, D. Camerarius (1627) ${ }^{6}$ ) calls B. simply episcopus Sodorensis.

c) Adam King $(1588)^{7}$ ) places B. vnder kink kennete 3. A. D. 1000; Thomas Dempster $(1627)^{8}$ ) has A. D. 1010. King Kenneth III ruled A. D. $997-1005 .{ }^{9}$ )

\section{Orkneys.}

There does not exist any chronicle of the bishops of Orkneys written within the diocese itself. The Norwegian sources of the story of the Orkneys naturally deal very slightly with preNorwegian events: the Orkneyinga saga ${ }^{10}$ ) or (more correctly).Jarlasaga (written about 1200), i. e. the story of the jarlar (or counts) in the Orkneys, is here absolutely silent; the Historia Norvegiæ ${ }^{11}$ ) (written in the first part of the thirteenth century, now only existing in a collective codex from about 1460, written for the earl of the Orkneys) has only some few words about the aborigines of the isles, the Peti [i. e. Picts], and the Papa [i. e. Christian immigrants from Ireland]; the author does not even know that

1) Mart. of Tallaght, p. xxxi.

2) Mart. of Donegal, $214 \mathrm{f}$.

a) Mart. of Engus, 175. $184 \mathrm{f}$.

) The Book of Obits and Martyrology of Christ Church, Dublin, ed. J. C. Crosthwaite (Dublin, Irish Archæological Society 1844), 144.

5) A. S. Boll. 19/VII. ${ }^{3}$ XXXI, 579f.; 10/VIII. ${ }^{3}$ XXXVI, 560 f.

6) De statu hominis, 221.

7) Forbes, Kalendars, 159.

8) Hist. eccl. nr. 142 ( ${ }^{2} 81$ ).

9) E. W. Robertson, Scotland I, $91 \mathrm{f}$.

10) Best edition by G. Vigfusson in Icelandic sagas (Rer. Brit. scr. 88) I, London 1887.

11) Best edition by G: Storm in Monumenta historiæ Norvegiæ (Kristiania 1880), $69--124=203-228$. 
the latter were Christians, for he says: 'Papa vero propter albas, quibus ut clerici induebantur, vocati sunt, unde in Theutonica lingıa omnes clerici papa dicuntur. Adhuc quadam insula Papey $a b$ illis denominatur. Sed ut per habitum et apices librorum eorum ibidem derelictorum notatur, Africani fuerunt, judaismo adhorentes'1). The bishop series of the province of Nidaros ${ }^{2}$ ) (composed in the beginning of the fourteenth century) also include the Orkneys, but in most copies the first name is that of bishop William I (1102-1168), with whom the uninterrupted series of Norwegian bishops begins, and who is also designated by the epitaph on his tomb as the primus episcopus ${ }^{3}$ ); only one copy of the series mentions two of the bishops, who were consecrated by the archbishops of York before this William. Thus we see that no Norwegian source enumerates all the bishops of Roman obedience from the time of the Christianisation of the Orkneys, not to mention the Celtic bishops before the Norwegian occupation. The historian of the archbishops of Hamburg (Adamus Bremensis, who wrote about 1075) however says, on occasion of his account about the first [Norwegian] bishop Turolfus [i. e. pórolfr] (ca. 1050), that the Church in the Orkneys up to that time had been governed by English and Scotch bishops: 'Ad easdem insulas Orchadas, quamvis prius ab Anglorum et Scothorum episcopis regerentur, noster primas [Adalbert 1043-1072] iussu papae ordinavit Turolfum episcopum in civitatem Blasconam [for Birgsanam, i. e. Birsa in Mainland], qui omnium (i. e. episcoporum) curas ageret'.4) Adam himself names these bishops: Heinricus, who had been the sacellarius of King Knut $\left.(+1035),{ }^{5}\right)$ and whom probably the archbishop of York had sent to the Orkneys, and Johannes, ordained in Scotia ${ }^{6}$ ) (i. e. in Ireland), whom Adalbert himself had sent out to the Orkneys. Both these bishops afterwards left the islands and went to Iceland, evidently because the Norwegian population of the Orkneys wished, and also ob-

1) Mon. hist. Norv., 89.

2) For the bibliography see Dipl. Norv. XVII B, 186-188.

3) P. A. Munch, Samlede Afhandlinger II (1874), $558^{1}$.

4) Adami Bremensis Gesta Hammaburgensis ecclesiae pontificum IV c. 34 (ex rec. Lappenbergii in nsum scholarum ed. G. Waitz. 'Hannoverac 1876, p. 183).

s) ib. IV c. 8 (p. 159).

e) ib. III c. 70 (p. 151). 
tained, a kinsman as their bishop, the above mentioned Turolfus. Besides this Johannes (vide infra p. 378-379) no Celtic bishops in the Orkneys are to be found in mediæval sources. As, however, some ancient authors mention a few non-Norwegian names, it may be of interest to inquire into the value of their evidence ${ }^{1}$ ).

Prosper Aquitanus says in his chronicle (first edition A. D. 433), that pope Cœlestinus in 431 sent Palladius as the first bishop ad Scottos . . . ordinatus ${ }^{2}$ ). Johannes de Fordun ( $t$ about 1386) $^{3}$ ) says that Palladius coming to Scocia found there Servanus, whom he consecrated bishop. Johannes Major (1521) ${ }^{4}$ adds, that Servanus was sent ad Orchades insulas. Adam King (1588) ${ }^{5}$ ) names under July 1 S. Serffe bischop of orknay and confessor vnder king Eugenius 2. A. D. 443. - Thomas Dempster (1627) ${ }^{6}$ ) even knows of two (!) bishops in the Orkneys, S. Serfus A. D. 293 and S. Servanus A. D. 440. - However, Palladius is the same as the apostle of Ireland S. Patrick '), and Scoti are the people of Ireland - although we are not without ancient accounts which tell about S. Patrick's visiting Scotland ${ }^{8}$ ) - ; thus the story about Servanus is rather doubtful. That he existed is proved by Scottish place names ${ }^{9}$ ); but the confused and incompatible accounts of him are very variously interpreted.10)

Beda ( $†$ 735) tells in his Historia ecclesiastica $\left.{ }^{11}\right)$, that [in 640] a letter was sent from Rome $T(h) o m i a n o, C o l u m b a n o, C(h) r o m a n o$, Dinna(n)o et Baithano episcopis ... Scottis. Amongst these Irish

1) The following extract is translated by the author from Dipl. Norv. XVII B, 294-295. 197-198 (see above p. 359, note 6).

2) Monumenta Germaniæ historica, Auctores antiquissimi IX, 473, ed. Th. Mommsen.

3) Chronica gentis Scotorum III c. 8 (ed. W. F. Skene, Historians of Scotland I, 94).

4) Historia maioris Britanniæ, fol. xxiii.

5) Forbes, Kalendars, 156.

o) Hist. eccl. nr. 1032. 1030 ( ${ }^{2} 574 *$ * *573 f.).

7) B. W. Wells, St. Patrick's Earlier Life, in English Historical Review V (1890), 475-485; H. Zimmer, in J. J. Herzog's Realencyklopädie ${ }^{3} \mathrm{X}, 215-217$.

8) Forbes, Kalendars, $427-430$.

9) Forbes, Kalendars, $445-447$.

${ }^{10}$ ) cf. A. S. Boll. 1/VII. ' XXVIII, 50-53; W. F. Skene, Celtic Scotland II, 184f.; J. O'Hanlon, Irish Saints IV, 248-253. V, 238. VII, 26-31.

11) II c. 19 (Patrologia, series latina, acc. J. P. Migne, XCV,113); Ph. Jaffé, Regesta Pontificum Romanorum ${ }^{2}$ nr. 2040. 
bishops Thomianus was archbishop of Armagh ( $+657 / 60){ }^{1}$ ) In the History of Hector Boethius (1526) ${ }^{2}$ ) they have all . become Scots, and the names corrupted: Connanum, Columbanum, Chroniacum, Dimaum, Bigitanum . . . episcopos. Johannes Leslæus (1578) ${ }^{3}$ ) repeats the series, and the first one is by him called Conuanus. Now Arnoldus Wion ${ }^{4}$ ) names among undated saints Convanus Scotus, monachus Insula Helluensis A. D. 640. By an easy combination D. Camerarius (1627), ) made Conran(n)us bishop in the Orkneys; his feast he (in 1631) ${ }^{\circ}$ ) placed on February 14.

Thomas Dempster, in his Menologium (1622) ${ }^{7}$ ) under April 6 mentions Kirkuae [i. e. in Kirkwaw] (festum) Berthami episcopi Orcadum sanctissimi; in his Historia ecclesiastica $\left.(1627)^{8}\right)$ he writes more reservedly: episcopus, sed cujus ecclesice incertum; putatur Orcadum (!). Adam King $(1588)^{\circ}$ ) in his Kalendary April 6 places S. Bercham bishop and confessor in scotland vnder king kennede A. D. 839 - king Kenneth I ruled A. D. 843 till $859^{10}$ ) -. A. P. Forbes ${ }^{11}$ ), certainly : with justification, considers this saint as identical with bishop Bearchan of Cluain-sosta (Clonsost) in Ui-Failghe, King's Co. in Ireland, who is mentioned in Irish martyrologies under August 4. ${ }^{12}$ )

Adam King $(1588)^{13}$ ) in his Kalendary June 6 names S. Colme bischop and confessor in scotland vnder king kennethe 3. A. D. 1000 - Kenneth III reigned A. D. 997-1005 -; Thomas Dempster mentions in his Menologium (1622) ${ }^{14}$ ) June 6 Kirkuae [i. e. in Kirkwaw] (festum) Colmi Orcadum Apostoli, and in his Historia

1) J. O'Hanlon, Irish saints I, $158 \mathrm{f}$.

2) Scotorum historia lib. IX (2 17654-55).

8) De origine, moribus et rebus gestis Scotorum (Romæ 1578), 158.

4) Martyrologium, appendix to his Lignum vitæ (Venetiis 1595), quoted A. S. Boll. 14/II. 3 V, 742.

s) De statu hominis, $147 \mathrm{f}$.

-) Forbes, Kalendars, 234.

7) Furbes, Kalendars, 196.

8) Nr. 133 ( 276$)$.

9) Forbes, Kalendars, 149.

10) E. W. Robertson, Scotland II, Appendix A III.

11) Kalendars, 279.

12) J. O'Hanlon, Irish Saints VIII, 71; A. S. Boll. 6/IV. 3 X, 602.

13) Forbes, Kalendars, 154.

14) Forbes, Kalendars, 202. 
ecclesiastica (1627)') he calls C. episcopus Orcadum about 1010, consecrated in Rome, and makes him a contemporary and friend of pope Bonifacius VII [974 and 984-985]. D. Camerarius (1627) ${ }^{2}$ ) transfers S. Colmus episcopus Orcadum insularum to June $\dot{b}$, later on (in 1631) ${ }^{3}$ ) to March 3. - Probably we are here confronted by a localization of one of the numerous saints of the name Colman in Ireland and Scotland - the martyrology of Donegal (1630) names 96 different ones -.4)

Johannes was consecrated in Scotland (see a), [went to Germany], was sent to the Orkneys ${ }^{5}$ ) (see b) by Adalbert archbishop in Hamburg-Bremen [1043-1072], [left the islands on occasion of the consecration (in 1050?) of a native Norwegian (?) bishop] "), went to Iceland - where he was called Jóhann (or Jón) enn irsk $\left.i^{7},{ }^{8}\right)$-, laboured here ' $a$ few' $^{7}$ ) (or 'four') $)^{9}$ ) years, left the island [about 1054.(?), on occasion of the election (in 1053?) and consecration (in 1056) of a native Icelandic bishop] ${ }^{10}$ ) and returned to Germany - wherefore in one Icelandic source he is called hinn saxneski9) - was appointed bishop for the recently erected see of Meklenburg by archbishop Adalbert of Bremen ${ }^{11},{ }^{8}$ ) (see c); here J. worked among the Slavish population, until in an insurrection he was killed by the pagans at Rethre in 1066 November 10.12)

a) Adamus styles him Johannes in Scotia ordinatus, ${ }^{5}$ ) Johannes Scotus, ${ }^{11}$ ) or Johannes quidam Scotorum episcopus. ${ }^{13}$ ) Until the tenth century Scotia signifies merely Ireland, in the eleventh also Scotland. The words: Hyberniam, Scotorum

1) Nr. 267 ( 2159$)$.

2) De statu hominis, 206.

3) Forbes, Kalendars, 230 .

4) See also A. S. Boll. 9/III. ${ }^{3}$ VIII, 3; 6, VI. ${ }^{3} \mathrm{XXI}, 748$ f.; Forbes, Kalendars, 302-306; J. O'Haulon, Irish Saints III, $277 \mathrm{f}$.

5) Adamus Bremensis (ca. 1075) III c. 70 (p. 151); cf. schol. 94 (ib.).

•) Ad. IV c. 34 (p. 183), III c. 70 (p. 151).

7) Íslendingabók $(1122,1133)$ c. 8 (p. 10, ed. Th. Möbius, Leipzig 1869).

8) Flúngrvaka c. 3 (p. 64, Biskupasügur I, 185̌).

9) Landnámabók, viðbót I (p. 332, Íslendingasügur I, 1843).

10) See Dipl. Norv. XVII B, p. 259.

i1) Ad. III c. 20 (p. 110).

12) Ad. III c. 50 (p. 130f.).

18) Ad. III c. 70 (p. 152). 
patriam, quae nunc Irland dicitur,1) show that Adam knew the distinction between Ireland and Scotland; the 'Scotorum patria' in his mind is evidently identical with 'Scotia', as indicated in the epithets quoted above.

b) ad insulas Baltici maris by the scholiast of Adamus ${ }^{2}$ ) probably corresponds to in Sclavaniam in another scholion. ${ }^{3}$ )

c) It is very difficult to state ${ }^{4}$ ) the time of the erection; the episcopal see is known to. have existed in 1062.5)

\section{Shetland.}

Of Celtic Christianity or Celtic bishops in the isles of Shetland nothing is known from literature, either mediæval, or recent.

1) Ad. IV c. 10 (p. 161).

2) Ad. schol. 94 (p. 151).

3) Ad. schol. 81 (p. 131).

4) G. Dehio, Geschichte des Erzbistums Hamburg-Bremen (Berlin 1877) I, 187, and Kritische Ausführungen XIX, p. 69.

5) Hamburgisches Urkundenbuch, hg. J. M. Lappenberg (1842) I, nr. 90.

Christiania.

Oluf KousRud. 